\title{
Seasonal variation of phytoplankton assemblage in Hoa Binh reservoir, north of Vietnam
}

\author{
Biến động quần xã thực vật nổi tại hồ chứa Hòa Bình, Bắc Việt Nam \\ Research article
}

Duong, Thi Thuy ${ }^{*}$; Vu, Thi Nguyet ${ }^{1}$; Le, Thi Phuong Quynh²; Ho, Tu Cuong²; Hoang, Trung Kien ${ }^{1}$; Nguyen, Trung Kien ${ }^{1}$; Dang Dinh Kim ${ }^{1}$

${ }^{I}$ Institute of Environmental Technology; ${ }^{2}$ Institute of Natural Products Chemistry, Vietnam Academy of Science and Technology, 18 Hoang Quoc Viet, Cau Giay, Hanoi, Vietnam

\begin{abstract}
Algae provide an important role in aquatic food web and biochemical cycles in aquatic systems. They are affected by different environmental factors, such as $\mathrm{pH}$, light, temperature and nutrients. This study aimed to describe the composition abundance and density of phytoplankton in the Hoa Binh reservoir during period from March to December 2011. Phytoplankton samples were collected monthly at four sampling stations. Result obtained showed that 6 phytoplankton classes were recorded: Cyanobacteria, Chlorophyceae, Bacillariophyceae, Euglenophyceae, Dinophyceae and Cryptophyceae. Bacillariophyceae and Cyanobacteria were the most abundant phytoplankton families constituting $61 \%$ and $32 \%$ respectively of total phytoplankton community. Colonyforming and solitary filamentous-forming of Cyanobacteria group (e.g. Microcystis aeruginosa, M. wesenbergi and Oscillatoria sp. respectively) were a common component of phytoplankton community in the early summer and autumn periods (April and September). The total cell densities of phytoplankton varied seasonally from 84210 to $100 \times 106$ cell/L. Phytoplankton density varied with season with high values in early summer and winter (April and December) and low values in summer -autumn periods (from June to October)
\end{abstract}

Tảo đóng vai trò quan trọng trong mạng luói thức ăn và chu trình sinh địa hóa của thủy vưc và chúng chịu sư chi phối của nhiều yếu tố môi truờng nhu ánh sáng, $p H$, nhiệt độ và dinh duõng. Nghiên cưu này trình bày đa dạng thành phần loài và biến động sinh khối thực vật phù du tại hồ chứa Hòa Bình tù̀ tháng 3 đến tháng 12 năm 2011. Các mẫu thực vật nổi được thu thập hàng tháng tại 4 điểm. Kết quả đã xác định đuoọc 6 lớp tảo chính bao gồm: Vi khuẩn lam, tảo luc, tảo silic, tảo mắt, tảo giáp và tảo lông roi hai rãnh. Nhóm tảo silic và Vi khuẩn lam chiếm uu thế với độ phong phú tuoong đối là $61 \%$ và $32 \%$ tuơng ưng trong quần xã thực vật nổi. Vi khuẩn lam dạng tập đoàn và dạng sợi (Microcystis aeruginosa, M. wesenberg, Oscillatoria sp. tuonng úng) chiếm uu thế trong quần xã thực vật nổi vào các thời điểm đầu hè và mùa thu (tháng 4 và tháng 9). Tổng mạt độ tế bào thực vật nổi dao động tù 84210 đến $100 \times 10^{6}$ cell/L. Mật độ thực vật nổi biển động theo mùa với sinh khối tê bào cao vào đầu hè và mùa đông (tháng 4 và tháng 12) và sinh khối tế bào thấp vào các mùa hè và thu (tháng 6 đến tháng 10).

Keywords: phytoplankton community, cyanobacteria, reservoir, Hoa Binh, Vietnam

\section{Introduction}

Phytoplankton are primary producers and form the base of most freshwater and marine food webs. They play important roles in carbon, nutrient, and oxygen cycling in aquatic ecosystems (Khan, 2003; Kang et al., 2006; Adon et al, 2011). Due to their abundance, wide geographical distribution, short cycle, rapid responses to a broad range of environmental perturbation, phytoplankton have been used as bioindicators for a large range of environmental and climate changes. Phytoplankton is therefore considered as an ecologically important group in most aquatic systems. In different types of fresh aquatic ecosystems, changes in phytoplankton community are 
recognized as a good indicator of the trophic status and environmental quality since they usually respond rapidly to environmental changes such as eutrophication, acidificationand organic pollution (Reynolds, 1996). Moreover, phytoplankton integrates ecological variations over time and can provide the information concerning larger-scale and longer-term changes in ecosystem function, including shifts in nutrient cycles, food webs, and fisheries (Paerl and Peierls 2008). Extensive work in freshwater aquatic systems has focused on identifying factors related to phytoplankton community composition. Relationship between seasonal periodicity of phytoplankton assemblages and seasonal variations in physical forcing of mixing dynamics, temperature, nutrients and the solar cycle in freshwaters and oceans have pointed out in many studies (Anneville et al., 2002; Winder and Hunter., 2008). Several studies have focused on factors determining the temporal and spatial variability of plankton (Hamilton et al., 2011) with an emphasis on temperate lakes.

Phytoplankton assemblage structure in temperate rivers and lakes is usually controlled by factors such as water temparture, light density, nutrients and top-down control. However, hydrological mechanisms (river morphology, discharge), as well as dilution and turbidity, are fundamental to the occurrence of phytoplankton distributions in rivers (Reynolds, 2006; Soares et al., 2007). Phytoplankton successions in tropical aquatic systems are generally characterized by a distinct shift between dry and rainy seasons (Bouvy et al., 2006; Nweze., 2006). The present study aimed to determine temporal and spatial variation of phytoplankton assemblage in the reservoir Hoa Binh, north of Vietnam.

\section{Materials and methods}

\subsection{Study site}

The Hoa Binh reservoir $\left(20^{0} 00^{\prime}-106^{0} 00^{\prime}\right)$ was constructed in 1989 and located on the Da River, which is the largest tributary of the Red River system. The Red River basin is located in the northern and north-eastern parts of Vietnam and has a total catchment area of $169,000 \mathrm{~km}^{2}$. The Hoa Binh reservoir has an effective storage capacity of 9.5 $\mathrm{Mm}^{3}$ and a surface area of $208 \mathrm{~km}^{2}$. The major characteristics of this reservoir are described in Le et al. (2007).

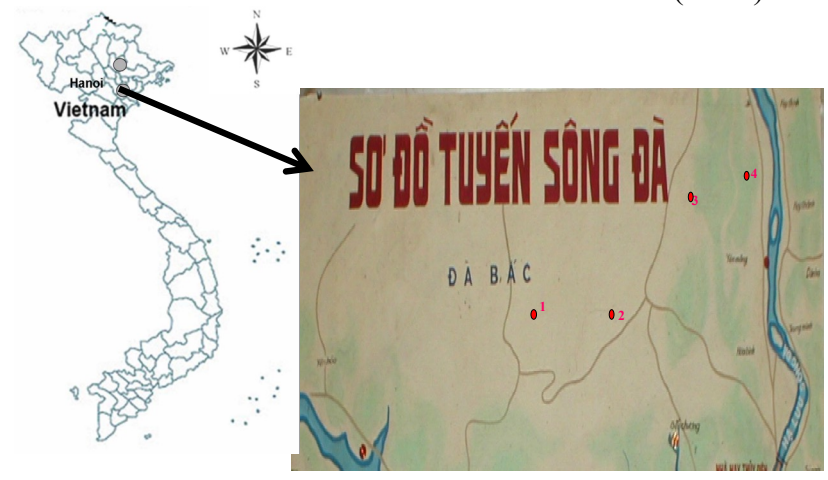

Figure 1. Sampling stations in the Hoa Binh reservoir
Average annual rainfall is about $1800-2000 \mathrm{~mm}, 80 \%$ of which occurs during the rainy season from June to October. The dry season lasts from November to April-May. Phytoplankton samples were taken monthly at four sampling sites from March to December 2011 (Figure 1). For the present study, the average values of sampling sites were presented.

\subsection{Sample collection and analysis}

Phytoplankton samples were collected monthly using plankton net (40 $\mu \mathrm{m}$ mesh size) and immediately fixed with formaldehyde solution at a $5 \%(\mathrm{v} / \mathrm{v})$ final concentration for species identification. Phytoplankton species were identified according to its morphology using light microscopic observation (Olympus BX51). The following taxonomic literature was used for the identification of cyanobacteria: Duong (1996); Komárek and Anagnostidis (1989; 1999; 2005). Krammer and Lange-Bertalot (19861991) was used for diatom identification. Den Hoek et al (1995), Duong and Vo (1997) were used for other algae identification. For phytoplankton enumeration, one-liter of water was preserved with $10 \mathrm{ml}$ Lugol's iodine solution and then was sedimented for $48 \mathrm{~h}$ prior to counting. Number of cells was counted by using a SedgewickRafter cell method (Karlson et al. 2010).

\section{Results and discussion}

Microscopic examination of phytoplankton assemblage in Hoa Binh reservoir from March to December 2011 revealed six groups: Chlorophyceae, Bacillariophyceae, Cryptophyceae, Euglenophyceae, Dinophyceae and Cyanobacteria. Figure 2 presents the abundance of phytoplankton groups in the study area during the investigated period. Generally, diatoms (Bacillariophyeae) and Cyanobacteria accounted the highest proportions in phytoplankton community in the Hoa Binh reservoir (up to $61 \%$ and $32 \%$, respectively), whereas Dinophyceae and Eugenophyceae had the lowest abundance.

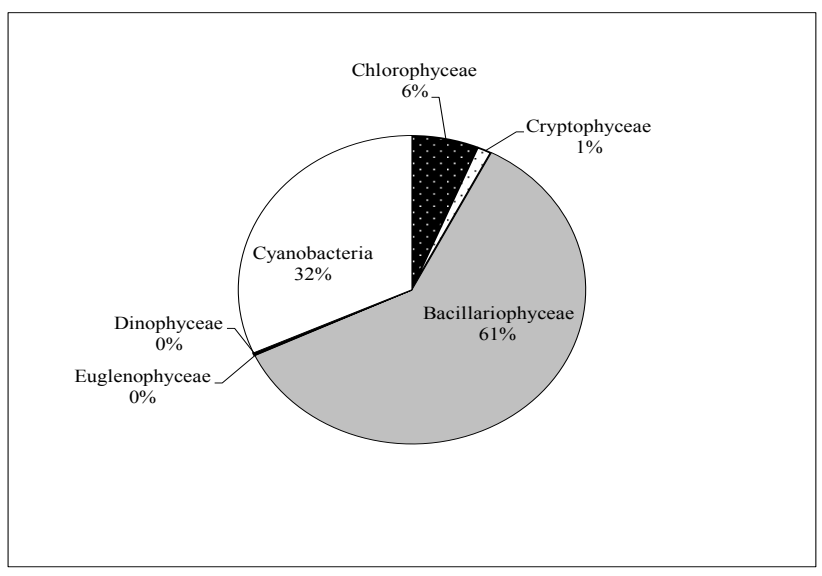

Figure 2. Percentage of 6 phytoplankton groups in the Hoa Binh reservoir (3-12/2011)

Similarly to temperate lakes, tropical aquatic ecosystems also may experience seasonal climatic variations that determine physical and chemical changes. Such variations, however, differ in amplitude and intensity (Fonseca 
and Bicudo, 2008). According to Frogg, 1975), different phytoplankton groups can tolerate different ranges of temperature, light and nutrient limitation. These tolerance levels identify the abundance of different phytoplankton groups within different seasons. During the study period, the Hoa Binh reservoir phytoplankton dynamic showed strong seasonal pattern (Fig 3). In early summer and autumn (April and September) phytoplankton community in the Hoa Binh reservoir dominated by filamentous forming
Cyanobacteria (e.g. Osillatoria ) or Microcystis sp. Chlorophyceae showed high development only from in summer from May to August and the phytoplankton community was then changed to be dominated by Cyanobacteria. Indeed, Cyanobacteria were the most important phytoplankton group in the eutrophic, mesotrophic temperate and trophic lake ecosystems in the summer/ autumn (Elliott, 2010).

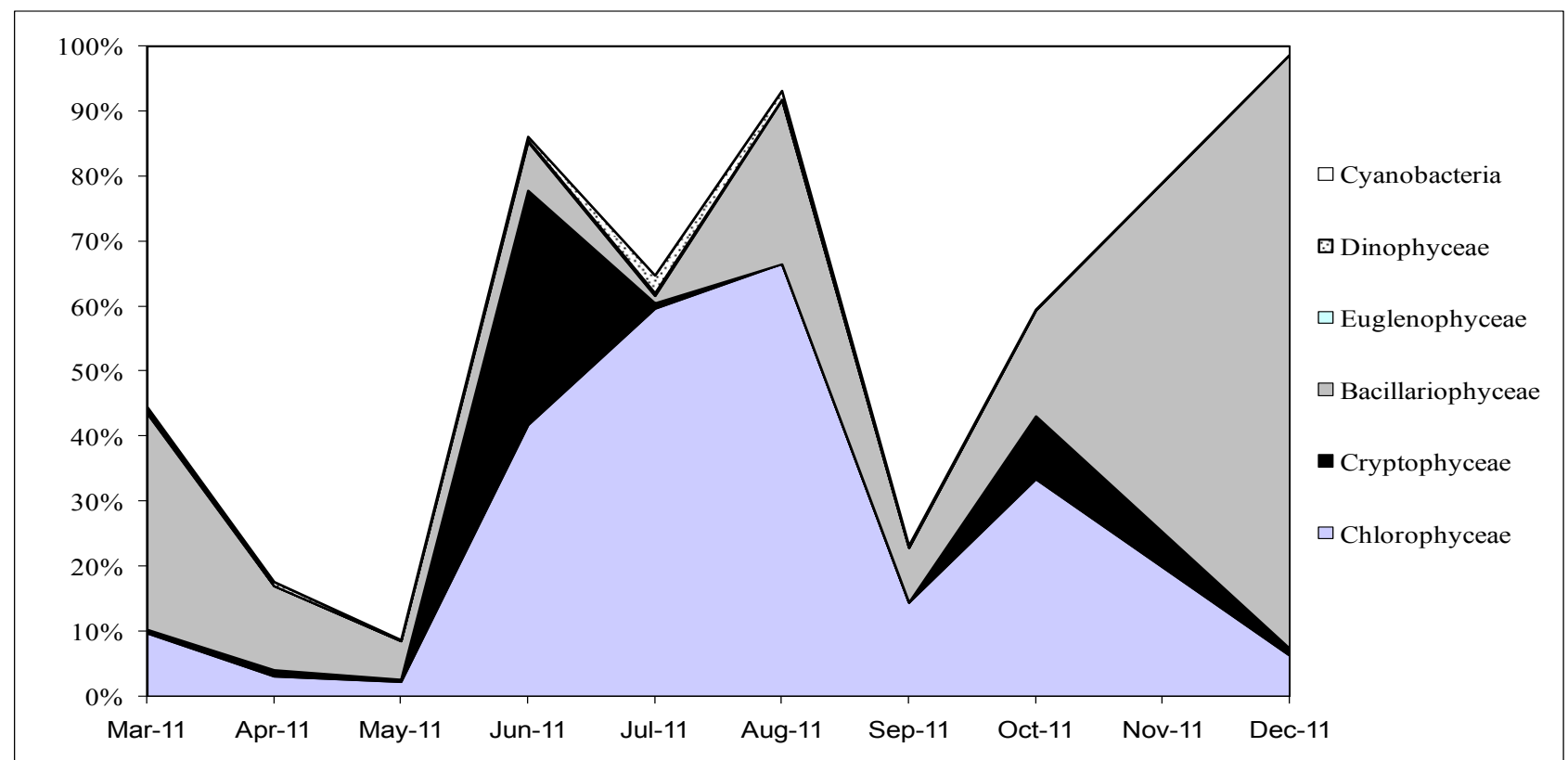

Figure 3. Seasonal variation of relative abundance of phytoplankton in the Hoa Binh reservoir during the study period from March to December 2011

Our results correspond to the observations of Salmaso (2000) who suggested that Chlorophytes and Cyanobacteria are the most typical algal groups, contributing to the aesthetic appearance and quality of the epilimnetic waters of the deep and large lakes located on the southern edge of the Alps. In fact, during cold period (in winter), Cyanobacteria and Chlorophyceae groups were replaced by diatom species (Bacillariophyceae). Phytoplankton successions in tropical aquatic systems are generally characterized by a distinct shift between dry and rainy seasons (Bouvy et al., 2006; Nweze., 2006). These results were consistent with those of other studies which found that phytoplankton succession in tropical aquatic systems was characterized by a distinct shift between dry and rainy seasons: Chlorophytes-chroococcales/ Cyanobacteria in the Lake Tanganyika (Descy et al. 2005), Diatoms/Cyanobacteria in the Lake Victoria (Kenya), the Lake Guiers (Senegal) and the Lake Dongping (Lung'ayia et al. 2000; Bouvy et al. 2006). Phytoplankton groups and dominant species in the Hoa Binh reservoir were presented in table 1. Phytoplankton composition of the Hoa Binh reservoir was cosmopolitant axa and common for freshwater and indicates eutrophic character of reservoir waters. The most frequently identified Cyanobacteria that occurred in the reservoir were colony-forming (e.g. $\mathrm{Mi}$ crocystis aeruginosa, $M$. wesenbergi) as well as the solitary filamentous-forming (e.g. Oscillatoria $s p$ ). These species have been previously described worldwide as potential cyanotoxin producers (Chorus and Bar- tram1999). These species have been not only found in this study but also in several fishponds and water bodies in Vietnam from earlier investigations (Dang et al.2005; Nguyen et al.2007; Dao et al. 2010).

Table 1. Dominant phytoplankton species in the Hoa Binh reservoir

\begin{tabular}{|c|c|}
\hline $\begin{array}{l}\text { Phytoplankton } \\
\text { groups }\end{array}$ & $\begin{array}{l}\text { Dominant } \\
\text { species }\end{array}$ \\
\hline Cyanobacteria & $\begin{array}{l}\text { Microcystis aeruginosa, } \\
\text { wesenbergii, Oscilatoria } \mathrm{sp} .\end{array}$ \\
\hline Chlorophyceae & $\begin{array}{l}\text { Scenedesmus acuminatus, } S . \\
\text { quadricauda, Pediastrum sim- } \\
\text { plex, P. duplex, Staurastrum sp. } \\
\text { Cosmarium sp. }\end{array}$ \\
\hline
\end{tabular}

Bacillariophyceae Aulacoseira granulata, Melosira varians, Navicula sp., Cyclotella meneghiniana.

Cryptophyceae Cryptomonas sp.

Dinophyceae Ceratium sp., Peridinium sp.

Euglenophyceae Euglena acus, Phacus sp.

The dominant species found in the phytoplankton samples consist of chain-forming diatoms (e.g. Aulacoseira granulate, Melosira variant) and centric diatom (e.g. Cyclotella meneghiniana). According to the above-cited taxonomic literature, the centric diatoms of the Hoa Binh reservoir 
have a preference for meso-eutrophic waters. Dominant species belonging to the Chlorophyceae group were Scenedesmus acuminatus, $S$ sp., Pediastrum simplex, Staurastrum sp... Cryptophyceae, Euglenophyceae, and Dinophyceae were also observed in much lower numbers. These groups were represented mostly by Cryptomonas sp., Euglena sp, and Ceratium sp., respectively. Similar data were given by Duong (2013) on phytoplankton samples from Nui Coc reservoir. Cell density was taken into account to give a general pattern of the characteristics of phytoplankton communities in the Hoa Binh reservoir. The mean number of phytoplankton cell ranged from 84210 to $100.3 \times 10^{6}$ cell/L (Figure 4 ).

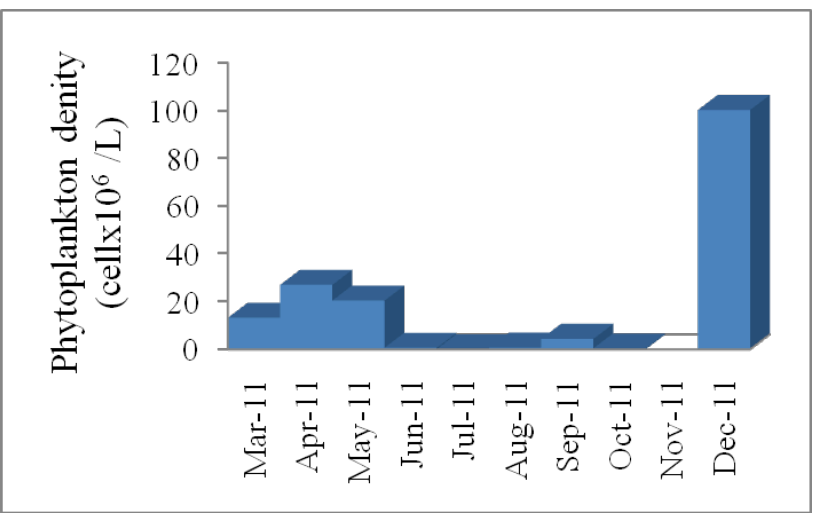

Figure 4. Density variation of phytoplankton $\left(\times 10^{6}\right)$ in the Hoa Binh reservoir in the period from March to December 2011

Phytoplankton density varied with season with high values in early summer and winter (April and December) and low values in summer - autumn periods (from June to October) (Figure 4). The two peaks of phytoplankton biomass during the early summer period was dominated by Cyanobacteria genus such as Microcystis and Oscillatoria $\left(20.2 \times 10^{6}\right.$ cell/L) and during winter period was caused by chain-forming diatoms Aulacoseira granulate and centric diatom Cyclotella $\left(100.3 \times 10^{6}\right.$ cell/L).

\section{Conclusions}

In conclusion, the results of this study revealed a generally clear seasonal pattern of changes in phytoplankton communities in the Hoa Binh reservoir. 6 phytoplankton classes were recorded: Cyanobacteria, Chlorophyceae, Bacillariophyceae, Euglenophyceae, Dinophyceae and Cryptophyceae. Among them, Bacillariophyceae and Cyanobacteria were the most abundant phytoplankton families constituting $61 \%$ and $32 \%$ respectively of total phytoplankton community. Our investigation indicated that, colony-forming and filamentous-forming of Cyanobacteria (e.g. Microcystis aeruginosa, M. wesenbergi and Oscillatoria sp. respectively) were dominated group of phytoplankton community during early summer and autumn periods (April and September). In summer, cyanobacteria were replaced by green algae (Chlorophyceae) group. There are distinctive seasonal differences of the phytoplankton abundance - higher in early summer and winter and autumn, lower in summer.

\section{Acknowledgments}

The authors are grateful for the financial supports from the NAFOSTED 106.16-2010.71 (the Vietnam's National Foundation for Science and Technology Development (NAFOSTED), from the International Foundation for Science (IFS W/4674-1) and from the Asia-Pacific Network for Global Change Research (APN).

\section{References}

[1] Adon, M.P., Ouattara, A., Gouene, G (2011). Seasonal variation in the diversity and abundance of phytoplankton in a small African tropical reservoir. In African Journal of Microbiology Research 18: 2616-2626.

[2] Anneville, O., Ginot, V., Duruart, J.C., Angeli, N (2002) Long-term study(1974-1998) of seasonal changes in the phytoplankton in.Lake Geneva: amulti-table approach. J Plankt Res 24: 993-1008.

[3] Bouvy, M., Ba, N., Ka, S., Sane, S., Pagano, M., Arfi, R (2006). Phytoplankton community structure and species assemblage succession in a shallow tropical lake (Lake Guiers, Senegal). Aquat Microb Ecol 45:147-161.

[4] Dang, D.K., Dang, H.P.H., Duong, T.T., Nguyen, S.N., Dang, T.T., Tran, V.T., Hoang, T.B., Le, T.T., Nguyen, T.C., Duong, D.T (2005) Toxic cyanobacteria in Vietnamese freshwater. Natl conf 12:289300 .

[5] Dao, T.S., Cronberg, G., Nimptsch, J., Do, H.L.C., Wiegand, C (2010) Toxic cyanobacteria from tri and reservoir, Vietnam. Nova Hedwigia 90:433-448.

[6] Duong DT (1996) Taxonomy of Cyanobacteria of Vietnam. Agriculture Publishing House, Hanoi. 122pp.

[7] Duong, D.T, Vo, H (1997) Fresh algae of Vietnam: taxonomy of chlor-ococcales. Agriculture publishing house, Hanoi, pp 503.

[8] Duong, T.T., Jähnichen, S., Le, T.P.Q., Ho, T.C., Hoang, T.K., Nguyen, TK., Vu, T.N., Dang, DK (2014). The occurrence of cyanobacteria and microcystins in the Hoan Kiem Lake and the Nui Coc reservoir (North Vietnam). Environmental Earth Sciences 71 (5): 2419-2427.

[9] Duong, T.T., Le, T.P.Q., Dao, T.S., Pflugmacher, S., Rochelle-Newall, E., Hoang, T.K., Vu, T.N., Dang, D.K (2013). Seasonal variation of cyanobacteria and microcystins in the Nui Coc Reservoir, Northern Vietnam. J Appl Phycol 25:1065-1075.

[10] Elliott, J.A (2010). The seasonal senstity of Cyanobacteria and other phytoplan on to changes influshing rate and water temperature. Global Change Biology, 16, 864-876.

[11] Fonseca, B.M., Bicudo, C.E.deM (2008). Phyto- 
plankton seasonal variation in a shallow stratified eutrophic reservoir (Garca pond, Brail). Hydrobiologia 600: 267-282.

[12] Kang, Y.S., Choi, H.C., Noh. J.H., Choi, K.J., Jeon, I.S (2006). Seasonal variation of phytoplankton community structure in Northeastern coastal waters off the Korean Peninsula. Alage 21: 83-90.

[13] Karlson, B., Cusack, C., Bresnan, E (2010) Microscopic and molecular methods for quantitative phytoplankton. Intergovernmental Oceanographic Commission of UNESCO, p109.

[14] Khan, T.A (2003). Limnology of four saline lakes in western Victoria, Australia. Limnologica 33: 327339

[15] Komárek, J., Anagnostidis, K (1989) Modern approach to the classification system of Cyanophytes 4-Nostocales. Arch fur Hydrobiol Suppl 82: 247345.

[16] Komárek, J., Anagnostidis, K (1999) Cyanoprokaryota, 1. Teil, Chroococcales. - In: Ettl, H., Gärtner, G., Heynig, H., Mollenhauer, D. (eds): Süsswasserflora von Mitteleuropa 19/1 (pp 1-548). Fischer Ver lag, Jena.

[17] Komárek, J., Anagnostidis, K (2005) Cyanoprokaryota-2. Teil/ 2nd Part: Oscillatoriales. In: Büdel, B., Krienitz, L., Gärtner, G., Schagerl, M. (Eds.), Süßwasserflora von Mitteleuropa 19/2. Elsevier/Spektrum, Heidelberg.

[18] Krammer, K., Lange-Betarlot, H (1986 - 1991) Bacillariophyceae. 1.Teil: Naviculaceae. 876 p; 2. Teil: Bacillariaceae, Epithemiaceae, Surirellaceae, 596 p; 3. Teil: Centrales, Fragilariaceae, Eunotiaceae, 576 p; 4. Teil: Achnanthaceae. Kritische Ergänzungen zu Navicula (Lineolatae) und Gomphonema. 437 p. In: H, Ettl Gerloff, J Heynig, H Mollenhauer, D. (Eds.), Süßwasserflora von Mitteleuropa. Gustav Fischer Verlag, Stuttgart, 2485 pp.

[19] Le, T.P.Q., Billen, G., Garnier, J., Théry, S., Chau.
V.M (2007). The changing of flow regime and sediment load of the Red River, Vietnam. J Hydrol 334: 199-214.

[20] Nguyen, L.T.T., Cronberg, G., Annadotter, H., Larsen, J (2007) Planktic cyanobacteria from freshwater localities in Thuathien-Hue Province, Vietnam II. Algal biomass and microcystin produc-tion. Nova Hedwigia 85:35-49.

[21] Nweze, N.O (2006) Seasonal variations in phytoplankton in Ogelube lake, a small natural West African lake. Lakes and Reservoirs Research and Management 11:63-72.

[22] Paerl, H.W., Rossignol, K.L., Hall, S.N., Peierls, B.L., Wetz, M.S (2010). Phytoplankton Phytoplankton community indicators of short- and long-term ecological change in the anthropogenically and climatically impacted neuse river estuary, north carolina, USA. Etuaries and Coasts 33: 485-497.

[23] Reynolds, C.S (1996). The plant life of the pelagic. Verh Int Ver Limnol 26: 97-113.

[24] Reynolds, C.S. (2006). The Ecology of Phytoplankton (Ecology, Biodiversity and Conservation). Cambridge University Press: Cambridge.

[25] Salmaso, N (2000). Factors affecting the seasonality and distribution of cyanobacteria and chlorophytes: a case study from the large lakes south of the Alps, with special reference to Lake Garda. Hydrobiologia 438 (1-3): 43-63.

[26] Soares, M.C.S., Huszar, V.L.M., Roland, F (2007). Phytoplanktonn dynamics in two tropical rivers with differenct degrees of human impact (Southeast Brazil) . River. Res. Appllic. 23: 698-714.

[27] Winder, M., Hunter, D.A (2008). Temporal organization of phytoplankton communities linked to physical forcing. Oecologia 156: 179-192. 